\title{
ACADEMIC PERFORMANCE AND MORAL COMPETENCE: A MATCH MADE IN HEAVEN?
}

\author{
* $^{1}$ Umaru Mustapha Zubairu; ${ }^{2}$ Chetubo Kuta Dauda; \\ ${ }^{3}$ Olalekan Busra Sakariyau; ${ }^{4}$ Isa Imam Paiko \\ ${ }^{1,2,3,4}$ Department of Entrepreneurship and Business Studies of Federal University of Technology \\ Minna, P.M.B 65, Gidan-Kwanu, Minna - Bida Road, Niger State
}

\begin{abstract}
This study aims to empirically assess the relationship between accounting students' academic performances and moral competencies by focusing on final-year accounting students enrolled at the International Islamic University Malaysia (IIUM). The students' moral competencies were measured using a scenario-based instrument developed through a collaboration with Islamic accounting scholars, called the Muslim Accountant Moral Competency Test (MAMOC), whilst students' academic performances were measured using their Cumulative Grade Point Averages (CGPAs). Contrary to the expected positive relationship between these two variables, the study found a negative, and insignificant, relationship. The implication of this result is that IIUM's Accounting Department needs to conduct a comprehensive review of the ethical content of its courses and use a more effective strategy of how to more effectively integrate Islamic values into the curriculum. Additionally, institutionalizing a measure of students' moral competencies would enable the department to objectively determine how well it is doing in developing the moral competencies of its students.
\end{abstract}

Keywords: moral competence, academic performance, higher education, Islamic perspective

How to cite item:

Zubairu, U., Dauda, C., Sakariyau, O., \& Paiko, I. (2016). Academic performance and moral competence: A match made in heaven?. Research and Evaluation in Education, 2(2), 206-219. doi:http://dx.doi.org/10.21831/reid.v2i2.8956

*Corresponding Author.

e-mail: uzubairu@gmail.com 


\section{Introduction}

The rash of financial scandals over the last two decades (Enron, WorldCom, Arthur Andersen, Parmalat, global financial crisis, etc.) has highlighted the steady moral decline amongst business people generally, and accountants specifically (Berg, 2015; Hemraj, 2015; Markham, 2015). This is because these scandals could not occur without complicity in guarding and preparing of critical financial information. To address this serious moral malaise amongst accountants, universities have been assigned to integrate ethics education into the accounting curriculum. It is expected that this will lead to the development of morally competent future accountants. In 2012, Malaysian government joined this crusade by releasing an educational blueprint which had as one of its main objectives the development of morally competent professionals by universities (Malaysia Education Blueprint 2013-2025, 2012).

The population of Malaysia's Muslim represents $61.3 \%$ of the total population (Department of Statistics, Malaysia, 2010). For this reason, the development of future Muslim accountants imbued with Islamic values is crucial in addressing the moral malaise amongst the country's accountants. Islamic universities in the country thus play a central role in achieving the government's morality mandate. These universities claim to be able to produce morally competent Muslim accountants by integrating Islamic values in every accounting course offered. If these claims are true, then it is logical to expect that students who do well in these courses will possess a high level of moral competence in an accounting context. In other words, there ought to be a positive correlation between Muslim accounting students' academic performances as determined by the Cumulative Grade Point Average (CGPA) and their moral competencies.

This study sought to empirically assess the existence of such a positive relationship between the accounting students' CGPA and their moral competencies by focusing on the final-year accounting students enrolled at the International Islamic University Malaysia (IIUM). Their moral competencies were mea- sured using a scenario-based instrument developed through a collaboration with Islamic accounting scholars, called Muslim Accountant Moral Competency Test (MAMOC).

The rest of the paper proceeds as follows. Firstly, the research paradigm adopted in this paper is described. This is followed by a review of the scholarship on the relationship between academic performance and moral competence. This paper's conceptual framework is then presented, followed by the research methodology adopted. The findings of the paper along with a discussion of their implications follow, and finally, the paper ends with a conclusion.

\section{Paradigm}

For Muslims, Islam represents a complete way of life. What this implies is that every aspect of a Muslim's life, including the conducting of research, is guided by the principles of Islam as embodied in its two primary sources of guidance, the Noble Quran and the Sunnab (teachings, deeds, sayings, and silent permissions of the Noble Prophet Muhammad [peace be upon him, PBUH]). The Sunnah is found in narrations by the companions of the Prophet Muhammad (PBUH) called Abadith (plural of hadith).

The implication of adopting this paradigm in conducting research is that all concepts identified in a study are defined in accordance with Islam's primary sources of guidance, rather than adopting conventional definitions of these concepts. Additionally, the expected relationships between these concepts are also derived from the Quran and Sunnah. This study embraces this paradigm, and this is particularly appropriate as the focus of the study is on the moral competencies of Muslim accounting students, and this concept can only be fully understood by referring to the source of all Muslim morality, the Quran and Sunnah. In order to shed more light on some verses of the Quran and Ahadith, commentaries by renowned Islamic scholars are also relied upon.

The review of relevant scholarship that explored the relationship between moral competence and academic performance revealed four streams of research based on the level of 
education of the students as follows: Stream one deals with elementary school students (Schaps, Solomon \& Watson, 1985; Benninga, Berkowitz, Kuehn, \& Smith, 2003; Snyder, Flay, Vuchinich, Acock, Washburn, Beets, \& Li, 2009; Hood, 2011); stream two deals with middle school students (Hightower, 2001; Flay et al., 2012; Elias, White, \& Stepney, 2014); stream three deals with high school students (Wynne \& Walberg, 1985; Mollman, 2004; Kariuki \& Williams, 2006; Lombardo, 2008; Griffin, 2011); and stream four deals with university students (Luttamaguzi, 2012; Olowookere, Alao, Odukoya, Adekeye, \& Ade'Agbude, 2015). These streams are later discussed in the paragraphs. The studies reviewed did not make explicit reference to 'moral competence', however they examined the relationship between academic performance and 'character'. Their conceptualization of character included traits like honesty, compassion, justice, perseverance and trustworthiness (Mollman, 2004; Lombardo, 2008); all these traits are what constitute a person's moral competence. For this reason, the term 'moral competence' is used in the place of 'character' in this review, so as to facilitate the flow of the paper, and avoid unnecessary confusion to the readers due to mere semantics.

\section{Stream One: Elementary Schools}

All four studies which were reviewed in this section took place in the United States of America, and all found a positive correlation between students' moral competencies and academic performance; the difference was in term of the strength of the correlation. Schaps et al. (1985) determine students' moral competencies through interviews and group-based task sessions, whilst teachers' observations were used in order to determine their academic performances. A small positive correlation was found between the two variables. Benninga et al. (2003) also find a small positive correlation between the two variables in their study. However, they employed different proxies for student moral competencies and academic performances; character education implementation levels were used as a proxy for moral competency, meanwhile, Stanford Achievement Test, $9^{\text {th }}$ edition (SAT-9) scores were used as a proxy for academic performance.

Snyder et al. (2009) used the same proxy for moral competence which was used by Benninga et al. (2003), but used the Hawaii Content and Performance Standard Scores to measure academic performance, instead of the SAT-9. They found a moderate positive correlation between student moral competencies and academic performance.

Character education implementation levels was also used by Hood (2011) as a proxy for moral competence, whilst the New Jersey School Report Card was used to ascertain academic performance. She found a strong positive correlation between student moral competencies and academic performances.

\section{Stream Two: Middle School}

Elias et al (2014) provide theoretical arguments as to the complementary relationship between moral competency and academic performance amongst middle school students. They urged all middle schools to establish character education programs so as to leverage this complementary relationship: Produce students with excellent characters and exemplary academic prowess.

Hightower (2001) and Flay et al. (2012) both studies conducted in the USA provide evidence that enabled Elias et al (2014) to posit that middle students' moral competencies are positively related to their academic performances. Hightower (2001) developed a questionnaire to measure middle students' moral competencies and used their SAT-9 scores as a proxy for their academic performances. She found a strong and positive relationship between these two variables.

The study of Flay et al.(2012) took place in Chicago, and they used the Value-Added Illinois State Achievement Test scores as a proxy for the academic performances of students in the study, whilst character education implementation levels served as a proxy for student moral competencies. After six years of the program, students from schools that implemented the program had 15\% better scores than students in the schools without the program. 
Stream Three: High School Students

Wynne and Walberg (1985), Mollman (2004), and Lombardo (2008) present normative arguments about the positive relationships between high school students' moral competency and academic performance. They conclude that all high schools should have dual goals of developing the moral competencies and academic performances of students.

The trend of US-based empirical studies continues with the study by Kariuki and Williams (2006). High school students at a military school were surveyed; their moral competencies were measured using a modification of a 'What do you really believe?' survey, whilst the Cumulative Grade Point Averages (CGPA) served as a measure of their academic performances. The results reveal a significant correlation between moral competence and academic performance.

In South Carolina, Griffin (2011) surveyed high school students, using their participation in a character development class as a proxy for their improved moral competencies. The students' grades in an English class before and after the character development class served as a measure of their academic performance. There are $62 \%$ of the students improved their pre-test scores, whilst $42 \%$ improved by a whole letter grade.

\section{Stream Four: University Students}

A study in Uganda by Luttamaguzi (2012) provides a different context from the US studies reviewed. The study focuses on education majors, and their moral competencies were measured using an author-developed questionnaire. Students' CGPAs served as measures of their academic performances. The results reveal a positive and significant relationship between the two variables.

Kern and Bowling (2015) take us back to the US, with a survey of law students whose moral competencies were measured using a Values in Action Character Strengths Inventory. Like Luttamaguzi (2012), Kern and Bowling (2015) used CGPA to serve as a measure of students' academic performances, and the results also show a positive relationship between moral competence and academic performance.
Olowookere et al. (2015) provide a Nigerian perspective on the relationship between students' moral competencies and academic performances by surveying the students enrolled in a Leadership Development Program. The authors developed a questionnaire called the 'Character Development Questionnaire' to measure the students' moral competencies, whilst CGPA was used to measure academic performance. Like all the studies reviewed, their study also found a positive relationship between these two variables.

\section{Observations from the Review}

The first observation is that all the studies reviewed either advocated for a positive relationship between student moral competence and academic performance, or provided empirical evidence of this positive relationship. This was despite the fact that different proxies were used to assess moral competence and academic performance. This body of evidence gives great credibility to the intuitive expectation expressed earlier in this paper that there should be a positive relationship between the moral competencies and academic performances of final-year accounting students enrolled at IIUM.

The second observation is that the vast majority of the studies already reviewed were conducted in the USA. There are only two studies (Luttamaguzi, 2012; Olowookere et al., 2015) that were conducted outside the US, and both were in Africa. This current study examines the relationship between moral competence and academic performance in a Malaysian context, thus giving an Asian perspective which seems to be absent from the current scholarship in this area.

The third observation is that the discussion of moral competence has been from either a secular or Christian perspective. This study provides an Islamic perspective which provides a different viewpoint, and thus contributes additional knowledge to the existing scholarship. Therefore, this study had two main concepts: Moral competence and academic performance. The conceptualizations of these concepts in this study, as well as the expected relationship between them from an Islamic perspective are presented below. 
Moral Competence

In this study, a morally competent Muslim accountant was defined as one who has the ability to make moral decisions in line with the commands of Allah in the Noble Quran, and in accordance with the Sunnah of the Noble Prophet Muhammad (PBUH), in discharging his or her duties as an accountant.

In Islam, this concept of moral competence is made up of two separate but interdependent parts: (1) Knowing the right thing to do (moral action), and (2) doing the right thing for Allah's sake alone (moral intention). In the sight of Almighty Allah, a moral action is only acceptable if the moral intention is solely for His pleasure. The Blessed Prophet Muhammad (PBUH) explains this very important point in the famous hadith narrated by Umar bin Al-Khattab:

The Messenger of Allah (PBUH) said, The deeds are considered by the intentions, and a person will get the reward according to his intention. So whoever emigrated for Allah and His Messenger, his emigration will be for Allah and His Messenger; and whoever emigrated for worldly benefits or for a woman to marry, his emigration would be for what he emigrated for' (Al-Nawawi, Book 1, Hadith 1).

This is a very crucial concept which this study took into consideration when assessing the moral competencies of final-year accounting students enrolled at IIUM. Figure 1 illustrates the above-mentioned conceptualization of moral competence.

Academic Performance

As mentioned in the paradigm section of this paper, Luttamaguzi (2012), Kern and
Bowling (2015), and Olowookere et al. (2015) all explore the relationship between students' moral competencies and academic performance in a university context. These three studies all utilized the students' CGPAs as a measure of their academic performances. Following their example, this study also used CGPA to capture students' academic performances.

Islamic Position on the Relationship between Academic Performance and Moral Competence

Islam is in agreement with the empirical evidence provided in the paradigm section of this paper that a positive relationship should exist between academic performance and moral competence. This is particularly true in IIUM's case where all accounting courses are supposed to be integrated with Islamic moral values. The following verse of the Noble Quran and hadith shed light on this issue:

And among people and moving creatures and grazing livestock are various colors similarly. Only those fear Allah, from among His servants, who have knowledge. Indeed, Allah is Exalted in Might and Forgiving (QS. Fatir: 28).

'The Prophet Muhammad (PBUH) said: "Verily, God loves if any of you does a job, he does it with perfection" (Al-Bayhaqi). Applying the verse above in the context of this study, the CGPA represents a measure of the students' knowledge about Islamic principles in an accounting context; those with the highest CGPA possess the most knowledge, and thus they ought to fear Allah the most; 'Fear of Allah' representing moral competence. In other words, the higher the CGPA, the higher the moral competence.

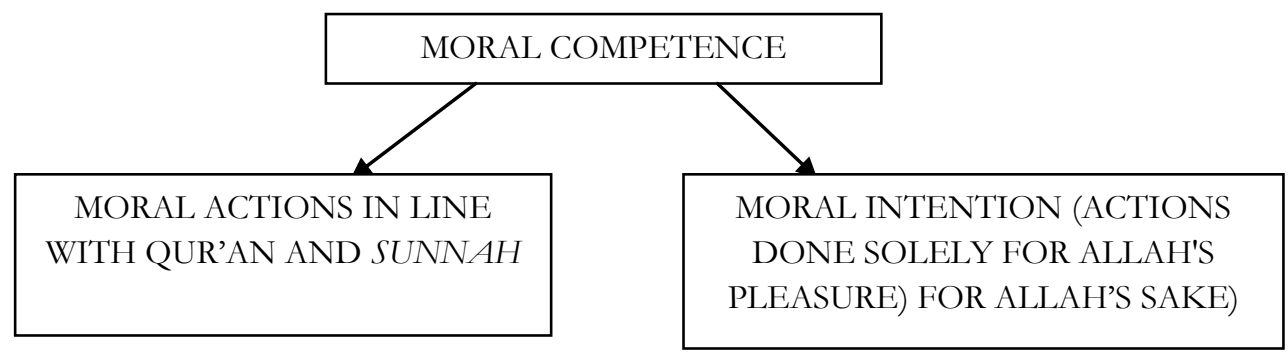

Figure 1: Conceptualization of Moral Competence 
Similarly, applying the hadith, moral competence represents one's level of obedience to God's commands. In the hadith, God commands humans to strive for perfection in all that we do. For the accounting students, those with the highest CGPA have striven the most to achieve perfection, thus displaying the highest level of moral competence. Moral competence and academic performance are positively related.

\section{Method}

This section presents the study's research design and methodology. Firstly, an overview of IIUM is provided, with particular emphasis on the Accounting Department from which the students that participated in the study belong to. Secondly, the steps followed to develop a profile of a morally competent Muslim accountant are presented. Thirdly, the steps followed to develop the instrument to measure the moral competencies of Muslim accounting students are presented. Finally, the actual procedure adopted for measuring the moral competencies of the specified students is discussed.

An Overview of the International Islamic University Malaysia (IIUM)

IIUM was established on 23rd May, 1983 based on the philosophy that all fields of knowledge should lead toward the recognition of, and submission to, the fact that Almighty Allah is the only one worthy of worship and is the Absolute Creator and Master of the universe. IIUM has a four-pronged mission of Integration, Islamization, Internationalization and Comprehensive Excellence (International Islamic University Malaysia, 2014). The university provides bachelors' degrees, masters' degrees and doctorate degrees in its 13 faculties called 'kulliyyahs'. Of particular interest to this study was IIUM's undergraduate accounting program accredited by the Malaysian Institute of Accountants (MIA). MIA accreditation of an accounting program is very important as only students that graduate from such programs can legally call themselves 'accountants' in Malaysia (Malaysian Institute of Accountants, 2012). IIUM's accounting program claims to integrate Islamic principles into contemporary accounting knowledge. In order to graduate, students are required to complete a minimum of 134 hours of a combination of university-required, kulliyyahrequired and departmental courses which includes practical trainings; three of the university-required courses have Islamic ethical content: (a) Islamic Worldview, (b) Islam, Knowledge and Civilization, and (c) Ethics and Fiqh for Everyday Life; four of the kulliyyah-required courses have Islamic ethical content. In addition, a recent Islamization initiative has mandated that ethical and Islamic content be integrated in all courses (International Islamic University Malaysia, 2014). At the time this study, IIUM department of accounting had 28 academic staff and 552 undergraduate students enrolled.

Developing the Profile of the Morally Competent Muslim Accountant

This section described the process adopted in order to develop the profile of a morally competent Muslim accountant. The profile was developed from the perspective of the Muslim accounting graduate, and was divided into two components: (1) Finding the 'right' job, and (2) Following an Islamic 'code of conduct'. A discussion of these two components is presented below.

\section{Finding the 'Right' Job}

Nu'man b. Bashir (Allah be pleased with him) reported: I heard Allah's Messenger (PBUH) as having said this (and Nu'man) pointed towards his ears with his fingers): What is lawful is evident and what is unlawful is evident, and in between them are the things doubtful which many people do not know. So be who guards against doubtful things keeps his religion and honor blameless, and be who indulges in doubtful things indulges in fact in unlawful things, just as a shepherd who pastures his animals round a preserve will soon pasture them in it. Beware, every king has a preserve, and the things God has declared unlawful are His preserves. Beware, in the body there is a piece of flesh; if it is sound, the whole body is sound and if it is corrupt the whole body is corrupt, and bearken it is the heart (Al-Hajiaj, 1599a, Book 22, Hadith 133). 
For a Muslim accounting graduate, the first challenge that faces him or her is finding the 'right' job. The 'right' job is one where all activities are in line with the Quran and Sunnah. As the hadith cited teaches us, the permissible jobs are clear and the prohibited jobs are clear, and the morally competent Muslim accountant must be able to make this distinction. The permissible activities are numerous in number, and thus the Muslim accountant has many options.

Say, My Lord has only forbidden immoralities what is apparent of them and what is concealed and sin, and oppression without right, and that you associate with Allah that for which $\mathrm{He}$ has not sent down authority, and that you say about Allah that which you do not know' (Q.S. Araf: 33).

However, there are certain kinds of jobs a Muslim accountant has to avoid because the activities that he or she engages in are incompatible with the commands of Almighty Allah. '...And cooperate in righteousness and piety, but do not cooperate in sin and aggression. And fear Allah; indeed, Allah is severe in penalty' (Q.S. Maeda: 2). Some of the most commonly known haram activities include (1) dealing in interest, (2) gambling, and (3) dealing with intoxicants.

After securing a job at an Allahapproved organization, the next concern for the morally competent Muslim accountant is to fulfil his or her duties in accordance with the commands of Almighty Allah. This 'Code of Conduct' represents the second component of the profile.

\section{Following an Islamic Code of Conduct}

As mentioned earlier in previous parts of this paper, every act of a morally competent Muslim must be done with the objective of earning the pleasure of The Most Gracious Allah. A Muslim accountant must thus keep this critical objective in mind whilst discharging his or her duties as an accountant. The objective of this component of the profile was to develop a comprehensive Islamic code of conduct that includes all the qualities that a morally Muslim accountant must display to please his Creator. In order to develop this code of conduct for Muslim accountants, the study adopted a two-pronged approach.

The first prong was to adopt the code of conduct for Muslim accountants developed by the Accounting and Auditing Organization for Islamic Financial Institutions (AAOIFI) as a foundation for this component of the profile. AAOIFI's code of conduct for Muslim accountants was first published in 1991 and is derived from the Noble Quran and Sunnab; this made it an excellent starting point. The AAOIFI's code of conduct contains five ethical principles described below:

Trustworthiness. The Muslim accountant should be straightforward and honest whilst discharging his or her duties, and must never present untruthful information.

Objectivity. The Muslim accountant should be fair, impartial and free from any conflict of interest.

Professional competence and diligence. The Muslim accountant must possess the requisite skill necessary to successfully discharge his duties.

Confidentiality. The Muslim accountant must never divulge information obtained about an organization during the course of discharging his or her duties without permission unless he or she is legally or professionally obliged to do so.

Professional conduct and technical standards. The Muslim accountant must observe the rules of professional conduct and obey the accounting and auditing standards of Shariahcompliant organizations.

The second prong was to interview and consult extensively with five Islamic scholars well versed in the Quran and Sunnah, particularly in the areas of 'Islamic accounting' as well as 'Fiqh Muamalat' (Laws of Islamic business transactions). These consultations established the content validity of AAOIFI's code of conduct. In addition to the five qualities listed by AAOIFI's code of conduct, the scholars suggested three more qualities to be added under the umbrella of 'Faith-Driven' conduct, which are unique to the Muslim accountant. These qualities include (1) avoiding interest, (2) avoiding gambling, and (3) avoiding physical contact with the opposite sex (ghairu mahram). 
In total the developed profile of the ideal Muslim accountant consisted nine key qualities: (1) Identifying the right job; (2) trustworthiness; (3) objectivity; (4) professional competence and diligence; (5) confidentiality; (6) professional conduct and technical standards; (7) avoiding interest; (8) avoiding gambling; (9) avoiding physical contact with the opposite sex. After the development of the two-component profile of a morally competent Muslim accountant was completed, the next step was to develop an instrument capable of effectively measuring the nine qualities contained in the profile.

Developing the Muslim Accountant Moral Competency Test (MAMOC)

A collaborative effort by the researchers and the five Islamic accounting and Fiqh Muamalat scholars resulted in the development of nine interrelated ethical scenarios to measure each of the nine qualities of a morally competent Muslim accountant highlighted above. The instrument developed was called 'The Muslim Accountant Moral Competency Test' or 'MAMOC'.

MAMOC has a title and three main sections: The instrument was titled 'Understanding the Career Aspirations and WorkRelated Decisions of Future Accountants'. In order to minimize social desirability bias amongst the respondents, the study's objective was disguised by giving the instrument this neutral heading without any obvious moral overtones. The first section was a demographic section with ten items (age, religion, gender, nationality, the question 'How often do you pray daily?', the question 'How important is religion in your family?', year of study, type of secondary school attended, the question 'How often do you visit your place of worship?' and CGPA). The second section was titled 'Choosing Your Dream Job'. Here, the respondents were given a choice of five job offers from companies in different industries. Each job offered had a company description, a job description, and an annual salary. This section sought to determine if the Muslim accounting students knew what the right job was from an Islamic perspective. To test this important aspect of the students' moral competencies, all the jobs offered were unacceptable from an Islamic perspective; it was expected that the morally competent student would recognize this, and consequently rejected all job offers on the basis of their unacceptability Islamically. The third section was titled 'Living Your Dream Job', and contained eight ethical scenarios, each of which testing each of the eight qualities of a morally competent accountant mentioned earlier [(1) Trustworthiness, (2) objectivity, (3) professional competence and diligence, (4) confidentiality, (5) professional conduct and technical standards, (6) avoiding interest, (7) avoiding gambling, (8) avoiding physical contact with the opposite sex]. The protagonist in the scenarios was a friend of the respondent, and the respondent was required to resolve the ethical dilemmas by advising his or her friend on what to do. The scenarios were structured in this way with the hope that respondents would be more honest in their answers if they were placed in an advisory capacity, rather than as the main actors in the scenarios. To conclude the instrument, the students were asked whether they would remain with the company after all the experiences contained in the previous scenarios.

The ethical scenarios contained in the instrument were then resolved by the scholars based on evidence from the Quran and Sunnah. Their solution served as the model answer to each scenario, and also served as a scoring guide for determining the moral competencies of the students surveyed.

A pilot study was carried out using the newly developed instrument to assess whether respondents would understand the instructions, terminology and content of the questionnaire. Additionally, the pilot study enabled the researcher to ascertain the reliability of the scoring system developed by the Islamic scholars. First-year Muslim students from the Economics and Management Faculty at IIUM were used to conduct the pilot study. These students were enrolled in four different sections of a Financial Accounting Fundamentals class, and were selected because they closely resembled the students selected for the actual study, final-year Muslim accounting students. A questionnaire was distributed to 100 stu- 
dents, and they were asked to carefully go through the questionnaire and ask any questions they might have as to its content. All the students stated that they clearly understood how to complete the questionnaires. The students were then told to take the questionnaires home, complete them, and bring them to the next class session. They were also told to write down how long it took them to complete the questionnaire. As many as 33 out of the 100 students returned the completed questionnaires.

An analysis of the completed questionnaires revealed that the students did indeed understand how to complete it. They provided well-thought out and clear resolutions to the various scenarios, and followed the stated instructions very well. The fact that first-year students could understand the instructions, content and terminology of MAMOC so well provided the researchers with confidence that the actual respondents of the study, final-year accounting students at IIUM, would understand just as well.

Savulescu, Crisp, Fulford, and Hope, (1999) explain that any instrument that is used in order to measure moral competence must be capable of being reliably applied by different raters. They also suggested that 'naive' raters should be utilized (naïve raters are those not involved in the development of the instrument). Following the advice proposed by Savulescu et al.(1999), after the pilot study was completed, the inter-rater reliability of the scoring system was assessed using the completed questionnaires from the pilot study; Inter-rater reliability is defined as 'the degree to which different judges or raters agree in their assessment decisions' (Phelan \& Wren, 2006). One of the researchers and one naive rater employed the model answers in order to assess the moral competencies of the students that participated in the pilot study. Halgren (2012) stated that Intra-Class Correlation (ICC) is the most commonly used statistical procedure to determine inter-rater reliability for studies that have two or more raters, with continuous variables. SPSS was used in order to calculate the instrument's inter-rater reliability using ICC. High ICC values indicate greater inter-rater reliability, with an ICC estimate of the 1 indicating perfect agreement and 0 indicating only random agreement. Negative ICC estimates indicate systematic disagreement between the raters (Halgren, 2012). After the completed pilot study questionnaires had been rated by one of the researchers and the naive rater, an Intra-Class correlation coefficient of 0.943 showed that the two raters had an almost perfect agreement when assessing the moral competencies of the pilot study participants. This result proved the reliability of the model answer for the assessment of students' moral competencies.

Another revelation of the pilot study was the fact that it took the students an average of thirty minutes to complete the questionnaire. This time was then used for the actual study. Finally, the pilot study revealed that the best approach for conducting the survey would be to get the students to complete the survey during class time, as opposed to letting them take it home and bringing it back during the next class session. By conducting the survey in class, the completed questionnaires were collected immediately, thus ensuring a much higher response rate in the actual study.

As specified in an earlier section of this paper, the moral competence (MC) from an Islamic perspective is a product of two components, namely: Moral action in line with the Quran and Sunnah (MA), and moral intention to please Almighty Allah alone (MI). Participating students were asked to resolve each scenario by stating the action they would advice their friend to take (MA), and providing a reason for that advice (MI). If a student's MA corresponded with the model MA, a score of 1 was given; if it did not, a score of 0 was given. The same rule applied for MI (1 for the correct reason, and 0 for incorrect reason). For each scenario, a student's MC = MA * MI. For a student to have a score for any scenario, both MA and MI must have corresponded with the model answers, otherwise he or she scored 0 for that scenario. Scores for each scenario were added to provide an overall MC score for each student; MC scores could range from a minimum of ' 0 ' to a maximum of ' 10 '. 
The students' academic performances were determined by their response to the CGPA item in the demographic information section of MAMOC. They had five options to choose from: $<2.00,2.00-2.50,2.51-3.00$, 3.01-3.50, and $>3.50$.

Measuring the Moral Competencies of Muslim Accounting Students of IIUM

Following the approach adopted in the pilot study, all sections of a compulsory finalyear accounting course were surveyed using MAMOC. There are 72 final-year students completed the questionnaire. The final-year students were selected for this study because they had completed most of the courses offered at IIUM, and thus were expected to have been imbued with all the Islamic values that had supposedly been integrated into the courses.

The relationship between the students' academic performances and their moral competencies was then determined using Spearman's Rank Order Correlation. This non-parametric technique was used instead of its parametric alternative, Pearson's product motion correlation, because the assumption of linearity was violated.

\section{Findings and Discussion}

This section of the paper presents the research findings and their implications. The descriptive statistics of the study's respondents is presented first. The relationship between the academic performances of IIUM final-year accounting students and their moral competencies as determined using Spearman's Rank Order Correlation is then presented. A discussion of the implications of the results concludes the section.

\section{Descriptive Statistics}

Table 1, 2 and 3 present descriptive statistics of IIUM accounting students surveyed in this study. Table 1 reveals that the majority of accounting students surveyed were female, representing $86.1 \%$ of the sample; Table 2 shows the distribution of the students' CGPAs, with the majority of students having a CGPA between 3.01 and 3.50, repre- senting $61.1 \%$ of the sample. Table 3 shows that the average age of the students was 23.47 years, and that their mean moral competence score was 5.39 out of a maximum of 10 .

Table 1. Gender

\begin{tabular}{llrr}
\hline & & Frequency & Percent \\
\hline \multirow{3}{*}{ Valid } & MALE & 10 & 13.9 \\
& FEMALE & 62 & 86.1 \\
& Total & 72 & 100.0 \\
\hline
\end{tabular}

Table 2. CGPA

\begin{tabular}{rlrr}
\hline & & Frequency & Percent \\
\hline \multirow{5}{*}{ Valid } & 2 TO 2.5 & 2 & 2.8 \\
& $2.51-3$ & 16 & 22.2 \\
& $3.01-3.5$ & 44 & 61.1 \\
& MORE THAN 3.5 & 10 & 13.9 \\
& Total & 72 & 100.0 \\
\hline
\end{tabular}

Table 3: Age and moral competence scores

\begin{tabular}{lrrrrr}
\hline & N & Min. & Max. & Mean & $\begin{array}{c}\text { Std. } \\
\text { Deviation }\end{array}$ \\
\hline AGE & 72 & 22 & 25 & 23.47 & .804 \\
MCSCORE & 72 & 2 & 10 & 5.39 & 2.268 \\
Valid N & 72 & & & & \\
(listwise) & & & & & \\
\hline
\end{tabular}

Determining the Relationship between IIUM Final-year Accounting Students' Aca-demic Performances and Their Moral Competencies

Table 4 presents the correlation between students' CGPAs and moral competence scores. The results are startling as they go against the grain of all previous studies reviewed in this paper. Rather than the expected positive correlation between the two variables, there was a negative correlation of -0.036 . However, the correlation was not statistically significant.

Cohen (1988) as cited by Pallant (2001) suggested the following interpretation of the strength of a correlation: 10 to .29 (small); .30 to .49 (medium); .50 to 1.0 (large). The correlation coefficient of -0.036 does not reach the threshold of a small correlation between the variables. The implication is that there is almost no relationship at all between the students' CGPA and their moral competencies.

Table 5 sheds more light on the surprising negative correlation between student's CGPAs and moral competence scores by pro- 
viding the correlation of CGPA with each ethical scenario contained in MAMOC. It is observed that there is a small but significant positive correlation between students' CGPAs and the fourth scenario which measured the students' professional competence. There is also a small but significant negative correlation between students' CGPA and the sixth scenario which measured students' understanding that gambling is forbidden in Islam.

\section{Discussion}

The basic premise of this study was that there would be a positive relationship between the academic performances and moral competencies of IIUM's final-year accounting students. This was based on the supposition that Islamic values were integrated into all the accounting courses at the university. However, the results revealed an unexpected negative, but insignificant, relationship between academic performance and moral competency. Further analysis revealed a small, positive and significant correlation between students' academic performances and their understanding of professional competence.

The implication of this results is that IIUM's Accounting Department needs to conduct a comprehensive review of the ethical coverage in the current curriculum. Focused strategies to integrate the nine attributes of a morally competent accountant identified in MAMOC must be developed and implemented by the accounting staff. It is also recommended that the issue of moral competence be given equal importance to academic achievement by the institutionalization of a measure of moral competence, which could be called the Moral Grade Point Average (MGPA), to go hand in hand with the traditional CGPA.

Regarding our second recommendation that moral competence be institutionalized, the Malaysian Ministry of Higher Education has reached the same conclusion. In 2015, the Ministry unveiled plans to institute a more holistic measure of university student performance titled 'The Integrated Cumulative Grade Point Average' (iCGPA) (Ann, 2015; Khor, 2015; Tay, 2015).

The iCGPA which has been the result of six years of research and consultations will be tested in selected faculties at five public universities: Universiti Kebangsaan Malaysia (UKM), Universiti Teknologi Mara (UiTM), Universiti Malaysia Terengganu, Universiti Malaysia Kelantan and Universiti Malaysia Pahang. The iCGPA is intended to provide a more comprehensive measure of student performance by addressing nine specific skill sets: (1) Knowledge and understanding, (2) practical skills, (3) social skills and responsibilities, (4) professional skills, ethics and values, (5) communication skills, leadership, and teamwork, (6) problem-solving skills and scientific thinking, (7) information management and lifelong learning, (8) entrepreneurship and management, and (9) unity and patriotism (Ann, 2015; Khor, 2015; Tay, 2015). The fourth skill set encompasses the important issue of moral competence.

Table 4. Correlation between CGPA and moral competence scores

\begin{tabular}{|c|c|c|c|c|}
\hline & & & CGPA & MCSCORE \\
\hline \multirow{6}{*}{ Spearman's rho } & \multirow{3}{*}{ CGPA } & $\begin{array}{l}\text { Correlation } \\
\text { Coefficient }\end{array}$ & 1.000 & -.036 \\
\hline & & Sig. (2-tailed) & . & .766 \\
\hline & & $\mathrm{N}$ & 72 & 72 \\
\hline & \multirow{3}{*}{ MCSCORE } & $\begin{array}{l}\text { Correlation } \\
\text { Coefficient }\end{array}$ & -.036 & 1.000 \\
\hline & & Sig. (2-tailed) & .766 & . \\
\hline & & $\mathrm{N}$ & 72 & 72 \\
\hline
\end{tabular}

Table 5. Correlation between CGPA and individual scenarios

\begin{tabular}{rcccccccccc}
\hline Scenario & 1 & 2 & 3 & 4 & 5 & 6 & 7 & 8 & 9 & 10 \\
\hline Correlation Coefficient & .014 & .079 & -.127 & $.234^{*}$ & .131 & $-.290^{*}$ & -.003 & -.063 & -.169 & -.166 \\
\hline \multicolumn{1}{c}{$*$ Correlation is significant at the .05 level (2-tailed) }
\end{tabular}




\section{Conclusion}

In Islam, true salvation lies in having a strong faith in Allah which is evidenced by sincerely obeying Him in all things. This is particularly important for Muslim accountants who play a crucial role as guardians and providers of crucial financial information which so many stakeholders rely upon.

IIUM is charged with the crucial task of producing morally-competent Muslim accountants who will restore the damaged credibility of accountants in Malaysia. To achieve this goal, IIUM's Accounting Department has integrated Islamic values into all its accounting courses. For this reason, it is expected that students who performed well in this courses would also possess a high level of moral competence. However, this study found a negative but insignificant relationship between the academic performances and moral competencies of IIUM's final-year accounting students. The implication of this result is that there is a need to revisit the ethical content of IIUM's accounting curriculum, as well as the process of integrating Islamic values into the accounting courses. Additionally, institutionalizing the measuring of students' moral competencies would enable IIUM to objectively determine how well it is doing in meeting its mandate of producing morally competent Muslim accountants. 'It is most hateful to Allah that you should say that which you do not do' (Q.S. Saff: 3).

\section{References}

Accounting and Auditing Organization for Islamic Financial Institutions. (2015). Accounting, auditing, and governance standards for Islamic financial institutions. Retrieved from http://aaoifi.com/ standard/accounting-standards/?lang= en

Al-Bayhaqi, A. B. (1994). Al-sunan alkubra. Beirut: Dar al-kutub al-ilmiyyah.

Al-Hajjaj, M. B. (2007). Sabib Muslim. Riyadh: Dar-us-salam Publications.
Al-Nawawi, I. (1999). Riyad-us-saliheen. Riyadh: Dar-us-salam Publications.

Ann, H. W. (2015). ICGPA - Too little, too late? Retrieved from http://www.bfm.my/ current-affairs-icgpa.html

Benninga, J. S., Berkowitz, M. W., Kuehn, P., \& Smith, K. (2003). The relationship of character education implementation and academic achievement in elementary schools. Journal of Research in Character Education, 1(1), 19-32.

Berg, M. (2015). Lending blind: Shadow banking and federal reserve governance in the global financial crisis. Annandale-On-Hudson, NY: Levy Economics Institute.

Department of Statistics, Malaysia (2010). Population distribution and basis demographic characteristics. Retrieved from https:// web.archive.org/web/20150301154300 /http://www.statistics.gov.my/portal/ download_Population/files/census2010 /Taburan_Penduduk_dan_Ciri-ciri_Asa s_Demografi.pdf

Elias, M. J., White, G., \& Stepney, C. (2014). Surmounting the challenges of improving academic performance: Closing the achievement gap through socialemotional and character development. Journal of Urban Learning, Teaching, and Research, 10, 14-24.

Flay, B. R., Acock, A., Vuchininch, S., Lewis, K., Bavarian, N., Schure, M., ... \& Ji, P. (2012). Social-emotional and character development to improve student behaviour and academic achievement: Results from two school-based randomized trials. In 2ND International Conference on the Future of Education, Florence, Italy.

Griffin, K. P. (2011). The effect of character education on the academic achievement of high school students. The Divergent Learning Journal, 25.

Halgren, K. A. (2012). Computing inter-rater reliability for observational data: An overview and tutorial. Tutor Quants Methods Psychol., 8(1), 23-34. 
Hemraj, M. (2015). US Statutory Regulation. In M. Hemraj (Ed.), Credit rating agencies: Self-regulation, statutory regulation and case law regulation in the United States and European Union (pp. 93-149). Switzerland: Springer International.

Hightower, M. A. B. (2001). The relationship between middle school students' level of character development and their behaviour, academic achievement, and attendance. Legacy ETDs. Paper 775. Retrieved from http://digitalcommons. georgiasouthern.edu/etd_legacy/775

Hood, K. L. (2011). Character education and parental involvement: Impact on academic achievement (Master's thesis). Rowan University, Glassboro, NJ.

International Islamic University Malaysia. (2014). Mission and vision. Retrieved from http://www.iium.edu.my/medicine/ab out-us/mission-vision

Kariuki, P. \& Williams, L. (2006). The relationship between character traits and academic performance of AFJROTC high school students. Retrieved from http:// files.eric.ed.gov/ fulltext/ED494959.pdf

Kern, M. L., \& Bowling, D. S. (2015). Character strengths and academic performance in law students. Journal of Research in Personality, 55, 25-29.

Khor, A. (2015). Towards an integrated grading system. Retrieved from http://www.thestar.com.my/News/Ed ucation/2015/08/16/Towards-an-inte grated-grading-system/

Lombardo, T. (2008). Ethical character development and personal and academic excellence. The wisdom page. Retrieved from www.wisdompage.com /Lombardo-EthicalCharacterDevelop ment2011.pdf

Luttamaguzi, J. B. (2012). Influence of moral aptitude on academic performance of the undergraduate students in school of education Makerere University. Kampala: Makarere University Institutional Repository.
Retrieved from http://dspace.mak.ac. ug/handle/10570/3810

Malaysia Education Blueprint 2013-2025 (2012). Develop values-driven Malaysians. Retrieved from http://www.moe.gov. my/userfiles/file/PPP/Preliminary-Blu eprint-Eng.pdf

Malaysian Institute of Accountants (2012). NIP Philosophy. Retrieved from http: //www.iim.org.my/en/falsafah-pin

Markham, J. W. (2015). A financial history of modern US corporate scandals: From enron to reform. New York, NY: Routledge.

Mollman, S. (2004). The effects of character education on positive self-esteem and academic achievement (Doctoral dissertation). University of Wisconsin-Stout, Menomonie, WI.

Olowookere, E. I., Alao, A. A., Odukoya, J. A., Adekeye, O. A., \& Ade'Agbude, G. (2015). Time management practices, character development and academic performance among University undergraduates: Covenant University experience. Creative Education, 6(01), 79.

Pallant, J. (2001). SPSS survival manual. Berkshire: McGraw-Hill Education.

Phelan, C., \& Wren, J. (2006). Exploring reliability in academic assessment. Retrieved from https://www.uni.edu/ chfasoa/reliabilityandvalidity.htm.

Savulescu, J., Crisp, R., Fulford, K. W., \& Hope, T. (1999). Evaluating ethics competence in medical education. Journal of Medical Ethics, 25(5), 367-374.

Schaps, E., Solomon, D., \& Watson, M. (1985). A program that combines character development and academic achievement. Educational Leadership, 43(4), 32-35.

Snyder, F., Flay, B., Vuchinich, S., Acock, A., Washburn, I., Beets, M., \& Li, K. K. (2009). Impact of a social-emotional and character development program on school-level indicators of academic achievement, absenteeism, and disciplinary outcomes: A matched-pair, cluster- 
randomized, controlled trial. Journal of Research on Educational Effectiveness, 3(1), 26-55.

Tay, E. (2015). Malaysia to roll out ICGPA programme. Retrieved from http:// highered.easyuni.com/2015/08/malaysi a-to-roll-ut-icgpa-programme/

Wynne, E. A., \& Walberg, H. J. (1985). The complementary goals of character development and academic excellence. Educational Leadership, 43(4), 15-18. 